\title{
Copper in cultivated soils of Finland
}

\begin{abstract}
MARKKU YLI-HALla
YLi-Halla, M. 1994. Copper in cultivated soils of Finland. Agricultural Science in Finland 3: 487-495. (Department of Applied Chemistry and Microbiology, P.O. Box 27, FIN-00014 University of Helsinki, Finland.)

Soil samples from the plough layers of 105 fields in different parts of Finland were analyzed for $\mathrm{Cu}$ fractions. Vertical distribution of $\mathrm{Cu}$ was also studied in a smaller material. Total $\mathrm{Cu}\left(\mathrm{Cu}_{10}, \mathrm{HNO}_{3}-\mathrm{HClO}_{4}-\mathrm{HF}-\mathrm{H}_{2} \mathrm{SO}_{4}\right.$ digestion) in the surface soil ranged 6.9-97.4 mg kg-1 (mean $37.1 \mathrm{mg} \mathrm{kg}^{-1}$ ) and was highest in clay soils (mean $59.0 \mathrm{mg} \mathrm{kg}^{-1}$ ) and lowest in fine sand and moraine soils (mean $18.3 \mathrm{mg} \mathrm{kg}^{-1}$ ). Copper in the water-soluble, exchangeable and mainly organically bound fraction was extracted with $0.1 \mathrm{M} \mathrm{K}_{4} \mathrm{P}_{2} \mathrm{O}_{7}\left(\mathrm{Cu}_{\mathrm{py}}\right)$, and $\mathrm{Cu}$ bound by poorly crystalline $\mathrm{Fe}, \mathrm{Al}$ and $\mathrm{Mn}$ oxides $\left(\mathrm{Cu}_{\mathrm{ox}}\right)$ was dissolved subsequently with $0.05 \mathrm{M}$ oxalate $(\mathrm{pH} 2.9)$. The average percentages of $\mathrm{Cu}_{\mathrm{py}}$ and $\mathrm{Cu}_{\mathrm{ox}}$ were $18 \%$ and $12 \%$ of $\mathrm{Cu}_{\text {tot }}$ in mineral soils and $34 \%$ and $19 \%$ of $\mathrm{Cu}_{\text {tof }}$ in organogenic soils, respectively. Residual $\mathrm{Cu}$ $\left(\mathrm{Cu}_{\text {res }}\right)$ incorporated in mineral lattices was calculated to constitute $70 \%$ and $47 \%$ of $\mathrm{Cu}_{\text {tot }}$ in mineral and organogenic soils, respectively. In two thirds of soils the potentially plant-available reserves of $\mathrm{Cu}\left(\mathrm{Cu}_{\mathrm{py}}+\mathrm{Cu}_{\mathrm{ox}}\right)$ were more plentiful than those of $\mathrm{Zn}\left(\mathrm{Zn}_{\mathrm{py}}+\mathrm{Zn}_{\mathrm{ox}}\right)$. An acetic acid - ammonium acetate - $\mathrm{Na}_{2}$ EDTA solution used in routine soil testing extracted $56 \%$ and $71 \%$ of the sum of $\mathrm{Cu}_{\mathrm{py}}+\mathrm{Cu}_{\mathrm{ox}}$ in mineral and organogenic soils, respectively. In soil profiles, $\mathrm{Cu}_{\mathrm{EDTA}}$ was higher in the plough layer than in the subsoil but a few soils rich in $\mathrm{Cu}_{\text {tot }}$ had abundant reserves of $\mathrm{Cu}_{\text {EDTA }}$ below the rooting depth of annual field crops.
\end{abstract}

Key words: total analysis, sequential extractions, pyrophosphate extraction, oxalate extraction, ammonium acetate-acetic acid-EDTA extraction, vertical distribution of $\mathrm{Cu}$, zinc

\section{Introduction}

Soil $\mathrm{Cu}$ is commonly divided into fractions with different extractants applied sequentially (McLaren and Crawford 1973, Shuman 1979, 1985, Liang et al. 1991). It is assumed that each solution dissolves a specific fraction retained by a given mechanism or soil constituent: $\mathrm{Cu}$ in soil solution, exchangeable, specifically adsorbed, complexed by organic matter or by $\mathrm{Fe}, \mathrm{Al}$ and $\mathrm{Mn}$ oxides and residual $\mathrm{Cu}$ incorporated mainly in the lattices of primary minerals (VIETS 1962). The residual fraction is considered unavailable to plants, while the other ones, collectively called secondary fractions, are, at least to some extent, sources of plant-available Cu (GALLARDO-LARA and Torres-Martin 1990, Liang et al. 1991). A few sediment samples mainly from polluted industrial areas of Finland have been analyzed for the fractions of $\mathrm{Cu}$ (RÄISÄNEN and HÄMÄLÄINEN 1991) but the fractional distribution of $\mathrm{Cu}$ in cultivated soils of the country is unknown.

An ammonium acetate - acetic acid - $\mathrm{Na}_{2}$ EDTA solution (AAAc-EDTA, pH 4.65) is used to extract $\mathrm{Cu}$ in soil testing in Finland. Recently, JOKINEN et al. (1993) found that this extractant dis- 
solved $40 \%$ of total $\mathrm{Cu}$ in organogenic soils. However, it is not known, either in organogenic or mineral soils, to what extent the secondary reserves, the potential source of plant-available $\mathrm{Cu}$, are extracted by this solution. This information would be important in order to be able to translate the soil testing results into a quantitative estimate of plant-available $\mathrm{Cu}$.

The purpose of the present study is to examine the distribution of soil $\mathrm{Cu}$ into different fractions using a simplified procedure of MCLAREN and CraWford (1973). The extraction power of AAAc - EDTA was studied and the results obtained by this method were related to the secondary fractions. The fractions of soil $\mathrm{Cu}$ were also compared to those of $\mathrm{Zn}$ obtained in a previous study (Yli-Halla 1993).

\section{Material and methods}

The distribution of $\mathrm{Cu}$ into various fractions was studied in 105 soil samples collected from the plough layers ( $A_{p}$ horizons) of cultivated fields in Finland. The material consisted of 25 clay soils, 20 silt and very fine sand soils, 26 fine sand and moraine soils, 14 mull soils and 20 peat soils. The vertical distribution of $\mathrm{Cu}$ was studied on seven soil profiles of cultivated fields as well as on 15 pairs of samples from the plough layer (A horizon) and from the respective subsoil (30$35 \mathrm{~cm}$ ). All the samples have been described in detail in an earlier study (Yli-Halla 1993). However, a moraine (soil 53) and a fine sand soil (soil 71) of the surface soil material of the previous study were not included in the present investigation.

To determine total $\mathrm{Cu}$, the soil was digested with a mixture of $\mathrm{HNO}_{3}, \mathrm{HClO}_{4}, \mathrm{HF}$ and $\mathrm{H}_{2} \mathrm{SO}_{4}$ (Yli-Halla 1993). Water-soluble and exchangeable $\mathrm{Cu}$ as well as $\mathrm{Cu}$ bound mostly by organic matter were extracted as one fraction with $0.1 \mathrm{M} \mathrm{K}_{4} \mathrm{P}_{2} \mathrm{O}_{7}(\mathrm{pH} 10)$, and $\mathrm{Cu}$ bound by poorly crystalline $\mathrm{Fe}, \mathrm{Al}$ and $\mathrm{Mn}$ oxides was extracted by a $0.05 \mathrm{M}$ oxalate solution $(0.026 \mathrm{M}$ ammonium oxalate, $0.024 \mathrm{M}$ oxalic acid, $\mathrm{pH} 2.9$ ) sequentially after the pyrophosphate extraction (YLI-
Halla 1993). In 16 representative soil samples, the residue remaining after the sequential pyrophosphate and oxalate extraction was further digested with a mixture of $\mathrm{HNO}_{3}, \mathrm{HClO}_{4}, \mathrm{HF}$ and $\mathrm{H}_{2} \mathrm{SO}_{4}$ to determine the residual $\mathrm{Cu}\left(\mathrm{Cu}_{\mathrm{res}}\right)$ but in most soil samples $\mathrm{Cu}_{\text {res }}$ was calculated as total $\mathrm{Cu}$ minus the sum of $\mathrm{Cu}$ extracted with pyrophosphate and oxalate, i.e. $\mathrm{Cu}_{\text {tot }}-\left(\mathrm{Cu}_{\mathrm{py}}+\mathrm{Cu}_{\mathrm{ox}}\right)$. All the digestions and extractions were carried out in duplicate. The $\mathrm{Cu}$ concentration of the extracts was determined by atomic absorption spectrophotometry. In order to allow a relevant comparison of $\mathrm{Cu}_{\text {tot }}, \mathrm{Cu}_{\mathrm{py}}, \mathrm{Cu}_{\mathrm{ox}}$ and $\mathrm{Cu}_{\mathrm{res}}$ between the mineral and organogenic soils, the results, originally expressed as milligrams per kilogram of soil, were in some instances transformed into milligrams per $\mathrm{dm}^{3}$ of soil by multiplying them with the bulk density. Copper was also extracted with a solution containing $0.5 \mathrm{M} \mathrm{CH}_{3} \mathrm{COONH}_{4}$, $0.5 \mathrm{M} \mathrm{CH}_{3} \mathrm{COOH}$ and $0.02 \mathrm{M} \mathrm{Na}_{2}-$ EDTA at $\mathrm{pH}$ 4.65 (LAKANEN and ERVIÖ 1971), which is the method used in soil testing in Finland.

\section{Results}

\section{Total copper}

In mineral soils, total $\mathrm{Cu}\left(\mathrm{Cu}_{\mathrm{tot}}, \mathrm{mg} \mathrm{kg}^{-1}\right)$ increased with increasing clay content $\left(r=0.87^{* * *}\right)$. In a few heavy clay soils, $\mathrm{Cu}_{\text {tot }}$ approached $100 \mathrm{mg} \mathrm{kg}^{-1}$, while in some fine sand soils it was very low $\left(<10 \mathrm{mg} \mathrm{kg}^{-1}\right)$ (Table 1$)$. Mull and peat soils had a similar concentration of $\mathrm{Cu}_{\text {tot }}$ but the number of very low contents of $\mathrm{Cu}_{\text {tot }}$ was higher among the peat soils. When expressing the results as milligrams per $\mathrm{dm}^{3}$ of soil, the averages were 26.8 and $14.7 \mathrm{mg} \mathrm{dm}^{-3}$ in mull and peat soils, respectively, being of the same level as the fine sand and moraine soils. In organogenic soils, $\mathrm{Cu}_{\text {tot }}\left(\mathrm{mg} \mathrm{dm}^{-3}\right)$ decreased with increasing organic $\mathrm{C}\left(\mathrm{r}=-0.52^{* *}\right)$.

\section{Fractions of soil copper}

In the 16 representative soil samples, $\mathrm{Cu}_{\text {tot }}$ and the sum of the fractions $\left(\mathrm{Cu}_{\mathrm{py}}+\mathrm{Cu}_{\mathrm{ox}}+\mathrm{Cu}_{\text {res }}\right)$ 
Table 1. Total $\mathrm{Cu}\left(\mathrm{Cu}_{\mathrm{tot}}\right)$ and $\mathrm{Cu}$ in fractions extracted with pyrophosphate $\left(\mathrm{Cu}_{\mathrm{py}}\right)$ and oxalate $\left(\mathrm{Cu}_{\mathrm{ox}}\right)$ and in the residual fraction $\left(\mathrm{Cu}_{\mathrm{res}}\right)$, and $\mathrm{Cu}$ extracted with AAAc-EDTA $\left(\mathrm{Cu}_{\mathrm{EDTA}}\right)$ as well as the bulk density of the plough layer soil samples. ${ }^{\prime}$

\begin{tabular}{|c|c|c|c|c|c|c|c|}
\hline \multicolumn{2}{|l|}{$\begin{array}{l}\text { Soil class and } \\
\text { number of samples }\end{array}$} & $\begin{array}{c}\text { Bulk density }{ }^{2} \\
\mathrm{~kg} \mathrm{dm}^{-3}\end{array}$ & $\mathrm{Cu}_{\text {tot }}$ & $\mathrm{Cu}_{\mathrm{py}} \mathrm{mg} \mathrm{kg}$ & $\mathrm{Cu}_{\mathrm{ox}}$ & $\mathrm{Cu}_{\mathrm{res}}$ & \multirow{2}{*}{$\begin{array}{r}\begin{array}{r}\mathrm{Cu}_{\mathrm{EDTA}} \\
\mathrm{mg} \mathrm{dm}^{-3}\end{array} \\
7.7^{\mathrm{a}} \\
2.5-26.0\end{array}$} \\
\hline $\begin{array}{l}\text { Clay } \\
\mathrm{n}=25\end{array}$ & $\begin{array}{l}\text { mean } \\
\text { range }\end{array}$ & $\begin{array}{r}0.96^{\mathrm{b}} \\
0.76-1.14\end{array}$ & $\begin{array}{r}59.0^{a} \\
31.6-97.4\end{array}$ & $\begin{array}{r}9.2^{\mathrm{a}} \\
2.9-26.9\end{array}$ & $\begin{array}{r}6.2^{\mathrm{a}} \\
2.4-20.8\end{array}$ & $\begin{array}{r}43.8^{\mathrm{a}} \\
12.4-77.8\end{array}$ & \\
\hline $\begin{array}{l}\text { Silt, very } \\
\text { fine sand, } n=20\end{array}$ & $\begin{array}{l}\text { mean } \\
\text { range }\end{array}$ & $\begin{array}{r}1.00^{b} \\
0.77-1.16\end{array}$ & $\begin{array}{r}30.7^{\mathrm{b}} \\
20.6-45.9\end{array}$ & $\begin{array}{r}4.3^{\mathrm{b}} \\
0.4-11.9\end{array}$ & $\begin{array}{r}3.1^{\mathrm{b}} \\
1.3-5.0\end{array}$ & $\begin{array}{r}23.4^{b} \\
7.7-36.8\end{array}$ & $\begin{array}{r}4.2^{b} \\
1.5-10.6\end{array}$ \\
\hline $\begin{array}{l}\text { Fine sand, } \\
\text { moraine, } n=26\end{array}$ & $\begin{array}{l}\text { mean } \\
\text { range }\end{array}$ & $\begin{array}{r}1.14^{a} \\
0.89-1.43\end{array}$ & $\begin{array}{r}16.3^{\mathrm{e}} \\
8.4-31.0\end{array}$ & $\begin{array}{r}3.3^{\mathrm{b}} \\
1.1-8.4^{-1}\end{array}$ & $\begin{array}{r}2.1^{\mathrm{b}} \\
0.7-5.4\end{array}$ & $\begin{array}{r}10.8^{c} \\
3.5-21.5\end{array}$ & $\begin{array}{r}3.7^{\mathrm{b}} \\
1.3-9.1\end{array}$ \\
\hline $\begin{array}{l}\text { Mull } \\
\mathrm{n}=14\end{array}$ & $\begin{array}{l}\text { mean } \\
\text { range }\end{array}$ & $\begin{array}{r}0.65^{c} \\
0.53-0.77\end{array}$ & $\begin{array}{r}41.4^{b} \\
21.0-80.5\end{array}$ & $\begin{array}{r}15.3^{\mathrm{a}} \\
3.9-26.2\end{array}$ & $\begin{array}{r}7.8^{\mathrm{a}} \\
2.8-14.9\end{array}$ & $\begin{array}{l}18.3^{\text {be }} \\
4.9-40.2^{2}\end{array}$ & $\begin{array}{r}8.1^{2} \\
3.0-14.1\end{array}$ \\
\hline $\begin{array}{l}\text { Peat } \\
n=20\end{array}$ & $\begin{array}{l}\text { mean } \\
\text { range }\end{array}$ & $\begin{array}{r}0.37^{d} \\
0.25-0.55\end{array}$ & $\begin{array}{r}38.5^{\mathrm{b}} \\
6.9-73.6\end{array}$ & $\begin{array}{r}12.9^{\mathrm{a}} \\
0.8-34.3\end{array}$ & $\begin{array}{r}7.7^{\mathrm{a}} \\
0.6-17.4\end{array}$ & $\begin{array}{c}17.9^{b c} \\
4.6-38.6\end{array}$ & $\begin{array}{r}5.9^{\text {at }} \\
0.9-14.9\end{array}$ \\
\hline
\end{tabular}

' The means in each column have been tested separately. Means marked with the same superscript within a column do not differ at $\mathrm{P}=0.05$.

${ }^{2}$ Determined by Yli-Halla (1993).

were $28.9 \mathrm{mg} \mathrm{kg}^{-1}$ and $33.0 \mathrm{mg} \mathrm{kg}^{-1}$, respectively. The difference between these figures in the individual soils ranged from -0.7 to $13.0 \mathrm{mg} \mathrm{kg}^{-1}$ (median $4.0 \mathrm{mg} \mathrm{kg}^{-1}$ ). Owing to the satisfactory recovery of $\mathrm{Cu}$ in the fractions, the determination of $\mathrm{Cu}_{\text {res }}$ was discontinued and the rest of the results of $\mathrm{Cu}_{\text {res }}$ were calculated as the difference $\mathrm{Cu}_{\text {tot }}-\left(\mathrm{Cu}_{\mathrm{py}}+\mathrm{Cu}_{\mathrm{ox}}\right)$.

The concentration of $\mathrm{Cu}$ extracted with pyrophosphate $\left(\mathrm{Cu}_{\mathrm{py}}\right.$, Table 1) was highest in mull and peat soils, but when expressing the results as $\mathrm{mg} \mathrm{dm}{ }^{-3}$ of soil, the mean of $9.8 \mathrm{mg} \mathrm{dm}^{-3}$ places the mull soils at the same level as clay soils. The mean of $5.1 \mathrm{mg} \mathrm{dm}^{-3}$ in peat soils equals that in silt and very fine sand soils. In most soils the concentration of $\mathrm{Cu}$ extracted with oxalate $\left(\mathrm{Cu}_{\mathrm{ox}}\right.$, Table 1) was smaller than $\mathrm{Cu}_{\mathrm{py}}$; only in 13 soils was $\mathrm{Cu}_{o x}$ equal to or higher than $\mathrm{Cu}_{\mathrm{py}} \cdot \mathrm{Cu}_{\mathrm{ox}}$ was at the same level in peat, mull and clay soils and substantially lower in coarse mineral soils. Both in mineral and organogenic soils, $\mathrm{Cu}_{\mathrm{py}}$ and $\mathrm{Cu}_{\mathrm{ox}}$ correlated highly with each other. In mineral soils, $\mathrm{Cu}_{\mathrm{py}}$ correlated highly significantly $(\mathrm{P}=0.001)$ also with clay and $\mathrm{Cu}_{\text {tot }}$ (Table 2), while $\mathrm{Cu}_{\mathrm{ox}}$ correlated with $\mathrm{Cu}_{\mathrm{tot}}, \mathrm{Cu}_{\mathrm{res}}$, clay and poorly crystalline $\mathrm{Fe}$ oxide $\left(\mathrm{Fe}_{\mathrm{ox}}\right)$. However, the partial cor- relation between $\mathrm{Cu}_{\mathrm{ox}}$ and $\mathrm{Fe}_{\mathrm{ox}}$, after the elimination of the effect of clay, was not significant $(\mathrm{P}=$ $0.05)$. In organogenic soils, both $\mathrm{Cu}_{\mathrm{py}}$ and $\mathrm{Cu}_{\mathrm{ox}}$ correlated most closely $(\mathrm{P}=0.001)$ with $\mathrm{Cu}_{\text {res }}$ and $\mathrm{Cu}_{\text {tot }}$.

Table 2. Correlation coefficients between copper extracted with pyrophosphate $\left(\mathrm{Cu}_{\mathrm{py}}\right)$ and oxalate $\left(\mathrm{Cu}_{\mathrm{ox}}\right)$ and soil properties in mineral and organogenic soils. The calculations have been carried out with the logarithmic $\left(\log _{10}\right)$ transformations of the concentrations of $\mathrm{Cu}\left(\mathrm{mg} \mathrm{dm}^{-3}\right)$ and $\mathrm{Fe}$ and $\mathrm{Al}\left(\mathrm{g} \mathrm{dm}^{-3}\right)$.

\begin{tabular}{|c|c|c|c|c|}
\hline \multirow{2}{*}{$\begin{array}{l}\text { Soil } \\
\text { characteristic }\end{array}$} & \multicolumn{2}{|c|}{ Mineral soils } & \multicolumn{2}{|c|}{ Organogenic soils } \\
\hline & $\mathrm{Cu}_{\mathrm{py}}$ & $\mathrm{Cu}_{\mathrm{ox}}$ & $\mathrm{Cu}_{\mathrm{py}}$ & $\mathrm{Cu}_{\mathrm{ox}}$ \\
\hline Clay & $0.52 \cdots$ & $0.68^{\cdots}$ & - & - \\
\hline Organic C & $0.32^{* *}$ & $0.09^{\text {ns. }}$ & $-0.52^{* *}$ & $-0.45^{* *}$ \\
\hline $\mathrm{Fe}_{\mathrm{ox}}{ }^{1}$ & $0.35^{*}$ & $0.44^{\cdots}$ & $0.50^{* *}$ & $0.48^{*}$ \\
\hline $\mathrm{Al}_{\mathrm{ox}}{ }^{1}$ & $0.24^{\text {ns. }}$ & $0.23^{\text {ns. }}$ & $0.47^{* *}$ & $0.22^{\mathrm{ns} .}$ \\
\hline $\mathrm{Cu}_{\mathrm{res}}$ & $0.38^{* *}$ & $0.62^{\cdots *}$ & $0.61^{\cdots \cdots}$ & $0.67^{* *}$ \\
\hline $\mathrm{Cu}_{\text {tot }}^{\text {res }}$ & $0.57 \cdots$ & $0.80^{* *}$ & $0.95^{\cdots *}$ & $0.91^{\cdots}$ \\
\hline $\mathrm{Cu}_{\mathrm{ox}}$ & $0.87^{\cdots *}$ & - & $0.90^{* * *}$ & - \\
\hline
\end{tabular}

${ }^{1}$ Extracted with $0.05 \mathrm{M}$ oxalate $(0.029 \mathrm{M}$ ammonium oxalate, $0.021 \mathrm{M}$ oxalic acid) at pH 3.3 (NISKANEN 1989). ;, ', '” Significant at $\mathrm{P}=0.05,0.01$ and 0.001 , respectively. n.s. Not significant $(\mathrm{P}>0.05)$. 
Table 3. Copper extracted with pyrophosphate $\left(\mathrm{Cu}_{\mathrm{py}}\right)$ and oxalate $\left(\mathrm{Cu}_{\mathrm{ox}}\right)$ as well as residual $\mathrm{Cu}\left(\mathrm{Cu}_{\mathrm{res}}\right)$ as percentages of total $\mathrm{Cu}{ }^{1}$

\begin{tabular}{|c|c|c|c|c|}
\hline \multicolumn{2}{|l|}{ Soil class } & \multirow{2}{*}{ 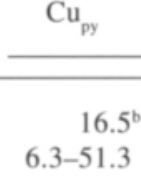 } & $\begin{array}{c}\mathrm{Cu}_{\mathrm{ox}} \\
\% \text { of total } \mathrm{Cu}\end{array}$ & $\mathrm{Cu}_{\text {res }}$ \\
\hline $\begin{array}{l}\text { Clay } \\
\mathrm{n}=25\end{array}$ & $\begin{array}{l}\text { mean } \\
\text { range }\end{array}$ & & $\begin{array}{r}10.5^{b} \\
5.3-22.1\end{array}$ & $\begin{array}{r}73.0^{\circ} \\
33.3-88.1\end{array}$ \\
\hline $\begin{array}{l}\text { Silt, very } \\
\text { fine sand } \\
\mathrm{n}=20\end{array}$ & & $\begin{array}{r}14.8^{b} \\
1.1-32.0\end{array}$ & $\begin{array}{r}10.6^{\mathrm{b}} \\
3.7-24.0\end{array}$ & $\begin{array}{r}75.4 \\
44.0-95.2\end{array}$ \\
\hline $\begin{array}{l}\text { Fine sand, } \\
\text { moraine } \\
n=26\end{array}$ & $\begin{array}{l}\text { mean } \\
\text { range }\end{array}$ & $\begin{array}{r}20.3^{b} \\
9.0-37.6\end{array}$ & $\begin{array}{r}13.1^{\mathrm{b}} \\
9.7-25.4\end{array}$ & $\begin{array}{r}66.6 \\
37.1-81.6\end{array}$ \\
\hline $\begin{array}{l}\text { Mull } \\
\mathrm{n}=14\end{array}$ & $\begin{array}{l}\text { mean } \\
\text { range }\end{array}$ & $\begin{array}{r}37.0^{\mathrm{a}} \\
18.6-62.5\end{array}$ & $\begin{array}{r}19.0^{a} \\
12.6-24.8\end{array}$ & $\begin{array}{r}44.0^{\prime} \\
14.1-63.5\end{array}$ \\
\hline $\begin{array}{l}\text { Peat } \\
n=20\end{array}$ & $\begin{array}{l}\text { mean } \\
\text { range }\end{array}$ & $\begin{array}{r}31.1^{\mathrm{a}} \\
11.6-50.1\end{array}$ & $\begin{array}{r}19.6^{\mathrm{a}} \\
8.7-35.8\end{array}$ & $\begin{array}{r}49.3 \\
16.0-68.7\end{array}$ \\
\hline
\end{tabular}

' The means in each column have been tested separately. Means marked with the same superscript within a column do not differ at $\mathrm{P}=0.05$.

In mineral soils, $29 \%$ of $\mathrm{Cu}_{\text {tot }}$ occurred in the secondary fractions $\left(\mathrm{Cu}_{\mathrm{py}}, \mathrm{Cu}_{\mathrm{ox}}\right)$, while these fractions constituted $53 \%$ of $\mathrm{Cu}_{\text {tot }}$ in the organogenic soils (Table 3). Even though in some organogenic soils more than half of soil $\mathrm{Cu}$ was in the form of $\mathrm{Cu}_{\mathrm{py}}, \mathrm{Cu}_{\mathrm{res}}$ was usually relatively the most abundant fraction in both soil groups. In mineral soils, the percentage of $\mathrm{Cu}_{\mathrm{py}}$ correlated weakly $\left(r=0.39^{* * *}\right)$ with organic $\mathrm{C}$ content.

\section{Copper extracted with AAAc-EDTA}

Copper extracted with AAAc-EDTA $\left(\mathrm{Cu}_{\text {EDTA }}\right.$, $\mathrm{mg} \mathrm{dm}^{-3}$ ) was highest in clay and mull soils (Table 1). The lowest result $\left(0.9 \mathrm{mg} \mathrm{dm}^{-3}\right)$ occurred in a Sphagnum peat soil which had been cultivated for five years. $\mathrm{Cu}_{\text {EDTA }}$ constituted on average $16 \%$ of $\mathrm{Cu}_{\text {tot }}$ in mineral soils and $42 \%$ in organogenic soils. In mineral and organogenic soils, AAAc-EDTA extracted $56 \%$ and $71 \%$ of the secondary $\mathrm{Cu}\left(\mathrm{Cu}_{\mathrm{py}}+\mathrm{Cu}_{\mathrm{ox}}, \mathrm{mg} \mathrm{dm}^{-3}\right)$, respectively. $\mathrm{Cu}_{\mathrm{EDTA}}$ correlated most strongly with $\mathrm{Cu}_{\mathrm{py}}$ and $\mathrm{Cu}_{\mathrm{ox}}$, in organogenic soils also with $\mathrm{Cu}_{\text {tot }}$ (Table 4). According to the regression analysis,
Table 4. Correlation coefficients ( $r$ ) between AAAc-EDTAextractable $\mathrm{Cu}$ and other indices of soil $\mathrm{Cu}$. The correlation coefficients have been calculated using the logarithms $\left(\log _{10}\right)$ of the results ( $\mathrm{mg} \mathrm{dm}^{-3}$ of soil).

\begin{tabular}{lcc}
\hline & \multicolumn{2}{c}{$\mathrm{r}$} \\
& Mineral soils & \\
\hline $\mathrm{Cu}_{\mathrm{py}}$ & $0.88^{\cdots}$ & $0.78^{\cdots \cdots}$ \\
$\mathrm{Cu}_{\mathrm{ox}}$ & $0.81^{\cdots}$ & $0.87^{\cdots \cdots}$ \\
$\mathrm{Cu}_{\text {tot }}$ & $0.56^{\cdots}$ & $0.76^{\cdots \cdots}$ \\
$\mathrm{Cu}_{\text {res }}$ & $0.35^{* *}$ & $0.45^{*}$ \\
\hline
\end{tabular}

$\because, \cdots$ Significant at $\mathrm{P}=0.01$ and 0.001 , respectively.

$\mathrm{Cu}_{\text {EDTA }}\left(\mathrm{mg} \mathrm{dm}^{-3}\right)$ increased with increasing $\mathrm{Cu}_{\mathrm{py}}$ $\left(\mathrm{mg} \mathrm{dm}^{-3}\right)$ and $\mathrm{Cu}_{\mathrm{ox}}\left(\mathrm{mg} \mathrm{dm}^{-3}\right)$ and with decreasing poorly crystalline $\mathrm{Al}$ oxide $\left(\mathrm{Al}_{\mathrm{ox}}, \mathrm{g} \mathrm{dm}^{-3}\right)$. The equations, calculated with the logarithms $\left(\log _{10}\right)$ of the results, were as follows:

Mineral soils:

$\log \mathrm{Cu}_{\mathrm{EDTA}}=0.66 \log \mathrm{Cu}_{\mathrm{py}}+0.23 \log \mathrm{Cu}_{\mathrm{ox}}$ $-0.24 \log \mathrm{Al}_{\text {ox }}+0.14$

$\mathrm{R}^{2}=0.82^{* *}$

Organogenic soils:

$\log \mathrm{Cu}_{\text {EDTA }}=0.43 \log \mathrm{Cu}_{\mathrm{py}}+0.34 \log \mathrm{Cu}_{\mathrm{ox}}$ $-0.31 \log \mathrm{Al}_{\mathrm{ox}}+0.28$

$R^{2}=0.86^{\cdots *}$

According to the $\beta$ coefficients (Table 5), $\mathrm{Cu}_{\mathrm{py}}$ was the dominant soil factor explaining the variation of $\mathrm{Cu}_{\mathrm{EDTA}}$ in both soil groups. In organogenic soils, $\mathrm{Cu}_{\text {ox }}$ and $\mathrm{Al}_{\text {ox }}$ appeared to be slightly

Table 5. t-Values of the regression coefficients and beta coefficients $(\beta)$ of the independent variables explaining the variation of $\log \mathrm{Cu}_{\mathrm{EDTA}}$ in mineral and organogenic soils.

\begin{tabular}{lccccc}
\hline $\begin{array}{l}\text { Independent } \\
\text { variable }\end{array}$ & \multicolumn{2}{c}{ Mineral soils } & & \multicolumn{2}{c}{ Organogenic soils } \\
\cline { 2 - 3 } \cline { 6 - 7 } & $\mathrm{t}$ & $\beta$ & & $\mathrm{t}$ & $\beta$ \\
\hline $\log \mathrm{Cu}_{\text {py }}$ & $6.88^{* *}$ & 0.73 & & $2.88^{* *}$ & 0.61 \\
$\log \mathrm{Cu}_{\text {ox }}$ & $2.05^{*}$ & 0.22 & & $2.18^{*}$ & 0.42 \\
$\log \mathrm{Al}$ & $-3.83^{\cdots *}$ & -0.21 & & $-4.51^{\cdots *}$ & -0.43 \\
\hline
\end{tabular}

$\because, \cdots, \cdots$ Significant at $\mathrm{P}=0.05,0.01$ and 0.001 , respectively. 
more important variables than in mineral soils, but this conclusion becomes less reliable due to the small number of organogenic soils in the material. Poorly crystalline $\mathrm{Fe}$ oxide $\left(\mathrm{Fe}_{\mathrm{ox}}\right)$ correlated with the secondary $\mathrm{Cu}$ fractions $\left(\mathrm{Cu}_{\mathrm{py}}, \mathrm{Cu}_{\mathrm{ox}}\right)$ and therefore $\mathrm{Fe}_{\mathrm{ox}}$ was not a statistically significant variable with $\mathrm{Cu}_{\mathrm{py}}$ and $\mathrm{Cu}_{\mathrm{ox}}$, whether or not $\mathrm{Al}_{\text {ox }}$ was in the equation. In organogenic soils there was a negative correlation $\left(r=-0.45^{* *}\right)$ between $\log \mathrm{Al}_{\text {ox }}$ and organic $\mathrm{C}$. The appearance of $\mathrm{Al}_{\text {ox }}$ in the above regression equation thus means that the extractability of $\mathrm{Cu}$ with AAAc-EDTA increases with increasing organic $\mathrm{C}$ and decreases with increasing mineral material.

\section{Vertical distribution of soil $\mathrm{Cu}$}

Except for profile 7 (P 7), $\mathrm{Cu}_{\text {tot }}$ was highest in all the profiles at the bottom (Table 6). The heavy clay layers in P 3 and the Carex peat sample taken from the bottom of P 5 had the highest $\mathrm{Cu}_{\text {tot }}\left(>100 \mathrm{mg} \mathrm{kg}^{-1}\right)$ of the entire material. Within the fine-textured mineral soil profiles P 1, P 2 and $\mathrm{P} 3, \mathrm{Cu}_{\text {tot }}$ increased with increasing clay content towards the deeper layers. In P 7 generally poor in $\mathrm{Cu}_{\text {tot }}$, the highest $\mathrm{Cu}_{\text {tot }}$ in the plough layer may originate from $\mathrm{Cu}$ fertilization. In the profiles $1,3,5$ and $6, \mathrm{Cu}_{\mathrm{EDTA}}$ was highest in the deepest layers, two-to-four times that in the plough layer while in the three remaining profiles, $\mathrm{Cu}_{\text {EDTA }}$ was highest in the plough layer.

In 14 sample pairs consisting of the plough layer $\left(\mathrm{A}_{\mathrm{p}}\right)$ and the subsoil (B) sample, $\mathrm{Cu}_{\mathrm{EDTA}}$ was significantly higher $\left(\mathrm{t}=3.375^{* *}\right.$ in the $\mathrm{t}$ test for paired measurements) in the plough layer. The means and ranges were as follows:

$\begin{array}{lll} & \text { Mean } & \text { Range } \\ \mathrm{A}_{\mathrm{p}} & 5.0 & 2.2-8.9 \\ \mathrm{~B} & 2.7 & 0.6-6.2\end{array}$

There were three pairs in which $\mathrm{Cu}_{\text {EDTA }}$ in the subsoil was equal to or slightly lower (0.3$1.0 \mathrm{mg} \mathrm{dm}^{-3}$ ) than in the plough layer. Of 15 sample pairs one pair not included in the above means had a heavy clay subsoil richer in $\mathrm{Cu}_{\mathrm{EDTA}}$ $\left(18.4 \mathrm{mg} \mathrm{dm}^{-3}\right)$ than the organogenic plough layer $\left(8.4 \mathrm{mg} \mathrm{dm}^{-3}\right)$.

\section{Comparison of soil $\mathrm{Cu}$ and $\mathrm{Zn}$}

In mineral soils, the reserves of $\mathrm{Cu}_{\text {tot }}\left(36 \mathrm{mg} \mathrm{kg}^{-1}\right)$ were substantially smaller than those of $\mathrm{Zn}_{\text {tot }}$ (94 $\mathrm{mg} \mathrm{kg}^{-1}$, for detailed results see YLI-HALLA 1993), but in organogenic soils the two elements occurred in the same quantities $\left(\mathrm{Cu}_{\text {tot }} 40 \mathrm{mg} \mathrm{kg}^{-1}\right.$, $\mathrm{Zn}_{\text {tot }} 41 \mathrm{mg} \mathrm{kg}^{-1}$ ). In two thirds of the soils the reserves of $\mathrm{Cu}$ in the secondary fractions $\left(\mathrm{Cu}_{\mathrm{py}}+\right.$ $\mathrm{Cu}_{\mathrm{ox}}$ ) were larger than those of $\mathrm{Zn}$. There were only 3 clay soils and 5 silt soils but as many as 16 coarse mineral soils and 8 peat soils where the secondary reserves of $\mathrm{Zn}$ exceeded those of $\mathrm{Cu}$. Accordingly, $\mathrm{Cu}_{\text {EDTA }}$ was lower than $\mathrm{Zn}_{\text {EDTA }}$ only in 21 soils. The correlation coefficients between the various indices of soil $\mathrm{Cu}$ with those of $\mathrm{Zn}$ were poorer in the organogenic soils than in the mineral soils (Table 7). It should be pointed out that in organogenic soils the correlation coefficients between $\mathrm{Cu}_{\mathrm{py}}$ and $\mathrm{Zn}_{\mathrm{py}}$ as well as between $\mathrm{Cu}_{\mathrm{EDTA}}$ and $\mathrm{Zn}_{\mathrm{EDTA}}$ were not statistically significant.

\section{Discussion}

In total $\mathrm{Cu}\left(\mathrm{Cu}_{\text {tot }}\right)$, the present soils corresponded to other soil materials from Finland (BAGHDADY and Sippola 1983, Koljonen and Malisa 1991, JOKINEN et al. 1993). They contained more $\mathrm{Cu}_{\text {to }}$ than the silty and sandy soils of England (mean $20.3 \mathrm{mg} \mathrm{kg}^{-1}$, range $5.2-63.5 \mathrm{mg} \mathrm{kg}^{-1}$, MCLAREN and CRAWFORD 1973) and clay and silt soils of Saskatchewan, Canada (mean $20.9 \mathrm{mg} \mathrm{kg}^{-1}$, range 6.5-39.0 mg kg-1, LiANG et al. 1991). Values of $\mathrm{Cu}_{\text {tot }}$ as high as those commonly found for the heavy clay soils in the present study are seldom reported in unpolluted cultivated soils elsewhere.

The mineral soils studied were richer in $\mathrm{Cu}_{\mathrm{EDTA}}$ than those of JOKINEN and TÄHTINEN (1987) who deliberately included soils where plants had shown symptoms of $\mathrm{Cu}$ deficiency. The mean $\mathrm{Cu}_{\mathrm{EDTA}}$ was also higher than in some other research materials $\left(2.8 \mathrm{mg} \mathrm{dm}^{-3}\right.$, SiPPOLA and TARES 1978 , SILlanPÄÄ 1982). Like in SIPPOLA and TARES (1978), $\mathrm{Cu}_{\mathrm{EDTA}}$ was higher in clay soils than in the other mineral soil classes. In organogenic soils, 
Table 6. Total $\mathrm{Cu}\left(\mathrm{Cu}_{\mathrm{tot}}\right)$ and $\mathrm{Cu}$ extracted with AAAc-EDTA $\left(\mathrm{Cu}_{\mathrm{EDTA}}\right)$ in samples taken from various depths in seven soil profiles.'

Profile 1: Tarvasjoki

loam $(0-38 \mathrm{~cm}) /$ clay loam $(38-120 \mathrm{~cm})$

$\begin{array}{lccccccc}\begin{array}{l}\text { Depth } \\ \mathrm{cm}\end{array} & \begin{array}{c}\text { Clay } \\ \%\end{array} & \begin{array}{c}\mathrm{Cu}_{\text {tot }} \\ \mathrm{mg} \mathrm{kg}^{-1}\end{array} & \begin{array}{c}\mathrm{Cu}_{\text {EDTA }} \\ \mathrm{mg} \mathrm{dm}^{-3}\end{array} & \begin{array}{l}\text { Depth } \\ \mathrm{cm}\end{array} & \begin{array}{c}\text { Clay } \\ \%\end{array} & \begin{array}{c}\mathrm{Cu}_{\text {tot }} \\ \mathrm{mg} \mathrm{kg}^{-1}\end{array} & \begin{array}{c}\mathrm{Cu}_{\text {EDTA }} \\ \mathrm{mg} \mathrm{dm}^{-3}\end{array} \\ 0-30 & 25 & 25.1^{\mathrm{f}} & 2.5^{\mathrm{e}} & 0-27 & 17 & 29.5^{\mathrm{d}} & 2.9^{\mathrm{a}} \\ 32-38 & 29 & 27.0^{\mathrm{c}} & 2.4^{\mathrm{e}} & 30-40 & 11 & 34.0^{\text {cd }} & 1.2^{\mathrm{d}} \\ 38-46 & 34 & 33.4^{\mathrm{d}} & 2.7^{\text {de }} & 40-50 & 12 & 37.5^{\mathrm{c}} & 1.3^{\mathrm{d}} \\ 50-60 & 41 & 40.5^{\mathrm{c}} & 3.2^{\mathrm{d}} & 50-70 & 17 & 48.5^{\mathrm{b}} & 1.6^{\mathrm{c}} \\ 65-80 & 51 & 51.2^{\mathrm{a}} & 3.8^{\mathrm{c}} & 70-90 & 6 & 26.5^{\mathrm{d}} & 0.9^{\mathrm{e}} \\ 85-100 & 56 & 47.5^{\mathrm{b}} & 4.8^{\mathrm{b}} & 90-100 & 16 & 48.5^{\mathrm{b}} & 1.6^{\mathrm{c}} \\ 105-120 & 55 & 48.0^{\mathrm{b}} & 9.8^{\mathrm{a}} & 110-120 & 27 & 62.6^{\mathrm{a}} & 2.0^{\mathrm{b}} \\ \text { HSD } & & 1.63 & 0.61 & \text { HSD } & & 7.67 & 0.18\end{array}$

Profile 3: Vihti

silty clay $(0-60 \mathrm{~cm}) /$ heavy clay $(60-120 \mathrm{~cm})$

$\begin{array}{lccccccc}\begin{array}{l}\text { Depth } \\ \mathrm{cm}\end{array} & \begin{array}{c}\text { Clay } \\ \%\end{array} & \begin{array}{c}\mathrm{Cu}_{\text {tot }} \\ \mathrm{mg} \mathrm{kg}^{-1}\end{array} & \begin{array}{c}\mathrm{Cu}_{\text {EDTA }} \\ \mathrm{mg} \mathrm{dm}^{-3}\end{array} & \begin{array}{l}\text { Depth } \\ \mathrm{cm}\end{array} & \begin{array}{c}\mathrm{FS}^{2} \\ \%\end{array} & \begin{array}{c}\mathrm{Cu}_{\text {tot }} \\ \mathrm{mg} \mathrm{kg}^{-1}\end{array} & \begin{array}{c}\mathrm{Cu}_{\text {EDTA }} \\ \mathrm{mg} \mathrm{dm}^{-3}\end{array} \\ 0-30 & 50 & 46.9^{\mathrm{e}} & 5.7^{\mathrm{c}} & 0-30 & 55 & 13.1^{\mathrm{b}} & 3.5^{\mathrm{a}} \\ 30-40 & 53 & 55.5^{\mathrm{d}} & 5.7^{\mathrm{c}} & 30-40 & 63 & 4.7^{\mathrm{e}} & 1.0^{\mathrm{c}} \\ 40-60 & 54 & 61.0^{\mathrm{c}} & 4.1^{\mathrm{d}} & 40-45 & 52 & 5.8^{\text {de }} & 1.4^{\mathrm{b}} \\ 60-80 & 72 & 67.7^{\mathrm{b}} & 6.4^{\mathrm{c}} & 45-60 & 67 & 6.7^{\mathrm{d}} & 0.9^{\mathrm{d}} \\ 80-100 & 88 & 108.9^{\mathrm{a}} & 9.3^{\mathrm{b}} & 60-80 & 75 & 8.0^{\mathrm{c}} & 0.7^{\mathrm{d}} \\ 100-120 & 76 & 109.2^{\mathrm{a}} & 10.5^{\mathrm{a}} & 80-110 & 82 & 12.6^{\mathrm{b}} & 1.3^{\mathrm{bc}} \\ \text { HSD } & & 5.13 & 0.79 & 110-120 & 64 & 15.4^{\mathrm{a}} & 1.0^{\mathrm{cd}} \\ & & & & \text { HSD } & & 1.43 & 0.31\end{array}$

Profile 5: Sotkamo, Carex peat $(20-120 \mathrm{~cm})$, mineral soil mixed in the plough layer

\begin{tabular}{|c|c|c|c|c|c|c|c|}
\hline $\begin{array}{l}\text { Depth } \\
\mathrm{cm}\end{array}$ & $\begin{array}{c}\text { Org. C } \\
\%\end{array}$ & $\begin{array}{c}\mathrm{Cu}_{\text {tot }} \\
\mathrm{mg} \mathrm{kg}^{-1}\end{array}$ & $\begin{array}{c}\mathrm{Cu}_{\mathrm{EDTA}} \\
\mathrm{mg} \mathrm{dm}^{-3}\end{array}$ & $\begin{array}{l}\text { Depth } \\
\mathrm{cm}\end{array}$ & $\begin{array}{c}\text { Org. C } \\
\%\end{array}$ & $\begin{array}{c}\mathrm{Cu}_{\text {tot }} \\
\mathrm{mg} \mathrm{kg}^{-1}\end{array}$ & $\begin{array}{c}\mathrm{Cu}_{\mathrm{EDTA}} \\
\mathrm{mg} \mathrm{dm}^{-3}\end{array}$ \\
\hline $0-20$ & 9 & $32.5^{e}$ & $10.5^{b}$ & $0-25$ & 31 & $51.2^{e}$ & $6.4^{c}$ \\
\hline $20-30$ & 52 & $23.8^{8}$ & $2.4^{g}$ & $30-40$ & 30 & $83.2^{c}$ & $11.5^{\mathrm{b}}$ \\
\hline $30-40$ & 49 & $27.6^{f}$ & $2.7^{8}$ & $40-45$ & 17 & $89.1^{\mathrm{b}}$ & $15.0^{\mathrm{ab}}$ \\
\hline $40-60$ & 52 & $35.4^{e}$ & $3.6^{f}$ & $50-70$ & 1 & $79.9^{d}$ & $17.0^{\mathrm{a}}$ \\
\hline $60-80$ & 47 & $46.8^{d}$ & $5.2^{e}$ & $70-80$ & 1 & $95.3^{\mathrm{a}}$ & $17.5^{a}$ \\
\hline $80-100$ & 40 & $55.7^{c}$ & $7.4^{\mathrm{d}}$ & HSD & & 1.98 & 4.05 \\
\hline $100-120$ & 31 & $65.5^{b}$ & $9.8^{\mathrm{c}}$ & & & & \\
\hline $120-130$ & 32 & $107.3^{a}$ & $20.5^{a}$ & & & & \\
\hline HSD & & 2.94 & 0.61 & & & & \\
\hline
\end{tabular}

Profile 7: Muhos

Carex peat $(0-110 \mathrm{~cm}) /$ fine sand $(110-125 \mathrm{~cm})$

\begin{tabular}{lcrc}
$\begin{array}{l}\text { Depth } \\
\mathrm{cm}\end{array}$ & $\begin{array}{c}\text { Org. C } \\
\%\end{array}$ & $\begin{array}{c}\mathrm{Cu}_{\text {tot }} \\
\mathrm{mg} \mathrm{kg}^{-1}\end{array}$ & $\begin{array}{c}\mathrm{Cu}_{\text {EDTA }} \\
\mathrm{mg} \mathrm{dm}^{-3}\end{array}$ \\
$0-30$ & 45 & $41.9^{\mathrm{a}}$ & $23.3^{\mathrm{a}}$ \\
$30-50$ & 55 & $2.7^{\mathrm{c}}$ & $0.9^{\mathrm{d}}$ \\
$50-70$ & 52 & $1.3^{\mathrm{c}}$ & $0.8^{\mathrm{d}}$ \\
$70-90$ & 56 & $4.9^{\mathrm{c}}$ & $1.3^{\mathrm{c}}$ \\
$90-110$ & 54 & $11.4^{\mathrm{b}}$ & $1.8^{\mathrm{b}}$ \\
$110-125$ & 0.2 & $2.8^{\mathrm{c}}$ & $0.7^{\mathrm{d}}$ \\
HSD & & 3.61 & 0.29 \\
\hline
\end{tabular}

${ }^{1}$ Each profile was tested separately for $\mathrm{Cu}_{\text {tot }}$ and $\mathrm{Cu}_{\mathrm{EDTA}}$. Means marked with the same superscript within a column do not differ at $\mathrm{P}=0.05$.

${ }^{2}$ Fine sand, $0.06-0.2 \mathrm{~mm}$ 
Table 7. Correlation coefficients ( $r$ ) between various indices of soil $\mathrm{Cu}$ and $\mathrm{Zn}$, calculated using the logarithms of the results ( $\mathrm{mg} \mathrm{dm}^{-3}$ of soil).

\begin{tabular}{|c|c|c|}
\hline $\begin{array}{l}\text { Correlation } \\
\text { coefficients between }\end{array}$ & $\begin{array}{l}\text { Mineral } \\
\text { soils }\end{array}$ & $\begin{array}{c}\text { Organogenic } \\
\text { soils }\end{array}$ \\
\hline $\mathrm{Cu}$ and $\mathrm{Zn}$ & $0.48^{* *}$ & $0.20^{\text {ns. }}$ \\
\hline $\mathrm{Cu}_{\mathrm{ox}}$ and $\mathrm{Zn}_{\mathrm{ox}}^{\mathrm{py}}$ & $0.65^{* \cdots}$ & $0.42^{\circ}$ \\
\hline $\mathrm{Cu}_{\mathrm{fes}}$ and $\mathrm{Zn}^{\mathrm{ox}}$ & $0.89^{* *}$ & $0.34^{\circ}$ \\
\hline $\mathrm{Cu}_{\mathrm{fot}}^{\text {res }}$ and $\mathrm{Zn}_{\mathrm{fot}}^{\text {res }}$ & $0.87^{\cdots}$ & $0.51^{* *}$ \\
\hline $\mathrm{Cu}_{\text {EDTA }}^{\text {tot }}$ and $\mathrm{Zn}_{\text {EDTA }}$ & $0.49^{* *}$ & $0.07^{\text {n.s. }}$ \\
\hline
\end{tabular}

$\because, \cdots, \cdots$ Significant at $\mathrm{P}=0.05,0.01$ and 0.001 , respectively.

n.s. Not significant $(\mathrm{P}>0.05)$.

mean $\mathrm{Cu}_{\mathrm{EDTA}}$ was similar to that reported by JoKINEN et al. (1993). The present soils also exhibited nearly the average $\mathrm{Cu}_{\mathrm{EDTA}}$ reported in routine soil testing in 1986-1988 (Viljavuuspalvelu - Soil Testing Service, Ltd., unpublished data) in over 60000 samples of mineral soils coarser than silt (mean $4.2 \mathrm{mg} \mathrm{dm}^{-3}$ ) and in over 25000 organogenic soils (mean $5.2 \mathrm{mg} \mathrm{dm}^{-3}$ ). The material of this study represents fairly well the average cultivated soils of Finland, even though there was only one soil classified as 'poor' in $\mathrm{Cu}\left(\mathrm{Cu}_{\mathrm{EDTA}}\right.$ below $1 \mathrm{mg} \mathrm{dm}^{-3}$ ) according to the interpretation of SillanPäÄ (1982).

The fraction of water-soluble and exchangeable $\mathrm{Cu}$ is too small to satisfy the needs of the plants (MCLAREN and CRAWFORD 1973, LiANG et al. 1991), and this readily plant-available form is replenished from other secondary fractions, especially from that bound by organic matter (LIANG et al. 1991). It was therefore considered appropriate in this study to include water-soluble, exchangeable and specifically adsorbed $\mathrm{Cu}$, together with $\mathrm{Cu}$ bound mainly by organic matter, in $\mathrm{Cu}_{\mathrm{py}}$ and not to extract them separately as is commonly done in fractionation procedures. $\mathrm{Cu}_{\mathrm{py}}$, expressed as percentages of $\mathrm{Cu}_{\mathrm{tot}}$, was in mineral soils at the same level as the sum of water-soluble, exchangeable, specifically adsorbed and organically bound $\mathrm{Cu}$ in soils of Saskatchewan, Canada (18.4\% of $\mathrm{Cu}_{\text {tot }}$, LiAng et al. 1991). Also $\mathrm{Cu}_{\mathrm{ox}}$ and $\mathrm{Cu}_{\text {res }}$ in the soils of Canada (11\% and $71 \%$ of $\mathrm{Cu}_{\text {tot }}$, respectively) were equal to those in texturally similar soils of the present study. In other studies (MCLAREN and CRAWFORD 1973, SHUMAN 1985), the relative sizes of the secondary fractions have been higher and those of $\mathrm{Cu}_{\text {res }}$ slightly lower $\left(\mathrm{Cu}_{\text {res }} 53 \%\right.$ and $65 \%$, respectively) than the relative sizes in the mineral soils of this investigation. In organogenic soils, the lower percentage of $\mathrm{Cu}_{\text {res }}$ and the higher ones of $\mathrm{Cu}_{\mathrm{py}}$ and $\mathrm{Cu}_{\mathrm{ox}}$ as compared to the mineral soils can be explained by the smaller quantity of mineral material, the source of $\mathrm{Cu}_{\text {res }}$.

Copper extracted with AAAc-EDTA has correlated rather closely with $\mathrm{Cu}$ supply to plants in pot experiments (SILlANPÄÄ 1982, ERVIÖ and SIPPOLA 1993). On the basis of the observation that the content of $\mathrm{Cu}_{\mathrm{py}}$ explained a great deal of the variation of $\mathrm{Cu}_{\mathrm{EDTA}}$ especially in mineral soils, it can be concluded that AAAc-EDTA dissolves $\mathrm{Cu}$ from the same reserves as does pyrophosphate. Also $\mathrm{Cu}$ bound by poorly crystalline oxides $\left(\mathrm{Cu}_{\mathrm{ox}}\right)$ can be plant-available (GALLARDO-LARA and TORRES-MARTIN 1990, LiANG et al. 1991) but according to MCLAREN and CRAWFORD (1973) $\mathrm{Cu}_{\text {ox }}$ is of minor importance as a source of plantavailable $\mathrm{Cu}$. The latter assumption is supported also by the results of the present study where $\mathrm{Cu}_{\text {ox }}$ relatively poorly explained the variation of $\mathrm{Cu}_{\text {EDTA }}$

In Finland, $\mathrm{Cu}$ deficiency in crop production has been reported especially in peat soils (TAINIO 1963, TÄHTINEN 1971). Even though quite a few peat soils may be low in $\mathrm{Cu}_{\text {tot }}$, the present results demonstrate that by far all of them are not poor in $\mathrm{Cu}_{\text {EDTA }}$. Therefore soil testing is necessary to recognize the soils where $\mathrm{Cu}$ fertilizers should be applied. In organogenic soils, AAAc-EDTA extracted a higher proportion of the potentially plantavailable $\mathrm{Cu}\left(\mathrm{Cu}_{\mathrm{py}}+\mathrm{Cu}_{\mathrm{ox}}\right)$ than in mineral soils. Thus, low $\mathrm{Cu}_{\mathrm{EDTA}}$ in organogenic soils implies for certain a scarcity of $\mathrm{Cu}$ and a probable requirement of $\mathrm{Cu}$ fertilization.

A higher $\mathrm{Cu}_{\text {EDTA }}$ in the plough layer, as compared to the B horizon, can partly be attributed to fertilizers, manures, atmospheric deposition and uplift of $\mathrm{Cu}$ by plant roots from below the plough layer. The higher content of organic matter may also enhance the solubility of $\mathrm{Cu}$ (SILLANPÄÄ 
1982). On the other hand, investigation of the soil profiles revealed that soils rich in $\mathrm{Cu}_{\text {tot }}$ had abundant reserves of $\mathrm{Cu}_{\text {EDTA }}$ also in the layers below the rooting depth of annual field crops. There, $\mathrm{Cu}$ released from primary minerals is not within the reach of plant roots and has obviously remained where the mineral was weathered. In the soils poor in $\mathrm{Cu}_{\text {tot }}$ this phenomenon was not observed, probably owing to the lack of weatherable $\mathrm{Cu}$-containing minerals. A similar vertical distribution of $\mathrm{Zn}_{\text {EDTA }}$ has earlier been observed in the same soil profiles (YLI-HALLA 1993).

In a recent study, carried out with the same soil samples (Yli-HaLla 1993), $90 \%$ of $\mathrm{Zn}_{\text {tot }}$ in mineral soils occurred as $\mathrm{Zn}_{\text {res }}$, while in the present investigation only $71 \%$ of $\mathrm{Cu}_{\text {tot }}$ occurred as $\mathrm{Cu}_{\text {res }}$. Accordingly, the percentages of the secondary fractions of $\mathrm{Cu}$ were higher than those of $\mathrm{Zn}$. Similar conclusions can be drawn also from the results of SHUMAN $(1979,1985)$ and LiANG et al. $(1990,1991)$. The difference between the distribution of $\mathrm{Cu}$ and $\mathrm{Zn}$ was even wider in the mull soils of the present study where $47 \%$ of $\mathrm{Cu}_{\text {tot }}$ and as much as $80 \%$ of $\mathrm{Zn}_{\text {tot }}$ occurred in the residual fraction. According to Mullins et al. (1982), fertilizer $\mathrm{Cu}$ and $\mathrm{Zn}$ are accumulated in forms extractable with pyrophosphate and oxalate. The relative abundance of secondary $\mathrm{Cu}$ fractions as compared to those of $\mathrm{Zn}$ as well as the poor correlation between the fractions of $\mathrm{Cu}$ and $\mathrm{Zn}$ in organogenic soils can partly be explained by addi- tions in $\mathrm{Cu}$ fertilizers, applied commonly in Finland since the 1950's. Zinc fertilization, as a rarer and a more recent practice, has probably contributed to a smaller increase in soil $\mathrm{Zn}$ content. Ample application of fertilizer $\mathrm{Cu}$ may also explain why even $\mathrm{Cu}_{\text {tot }}$ was equal to $\mathrm{Zn}_{\text {tot }}$ in organogenic soils, while in mineral soils $\mathrm{Cu}_{\text {tot }}$ was much lower than $\mathrm{Zn}_{\text {tot }}$. However, the secondary $\mathrm{Cu}$ fractions were more abundant than those of $\mathrm{Zn}$ also in mineral soils, and it is very unlikely that clay soils in particular have received either $\mathrm{Cu}$ or $\mathrm{Zn}$ in chemical fertilizers. The relative abundance of $\mathrm{Cu}$ in the secondary fractions therefore suggests that $\mathrm{Cu}$ minerals have weathered at a higher rate than those containing $\mathrm{Zn}$.

The sufficiency of plant nutrients in soil can, to some extent, be assessed by comparing the need of a plant for the plant-available reserves. In the study of YLÄRANTA and SILLANPÄÄ (1984), the $\mathrm{Zn}$ concentration was 5-11 times the concentration of $\mathrm{Cu}$ in cereal crops and 3-6 times that in forage crops. However, the size of the secondary $\mathrm{Cu}$ fractions in two thirds of the soil samples of the present study was higher than that of $\mathrm{Zn}$. Therefore, the reserves of plant-available $\mathrm{Cu}$ in average soils may be more abundant as related to plant uptake than those of $\mathrm{Zn}$.

Acknowledgements. The author wishes to thank Kemira Oy Espoo Research Centre for carrying out the chemical analyses of this investigation.

\section{References}

Baghdady, N. H. \& Sippola, J. 1983. Total heavy metal recovery by aqua regia in soils of different origin. Annales Agriculturae Fenniae 22: 175-185.

Gallardo-Lara, F. \& Torres-Martin, M. 1990. Dynamics of copper fractions in the soil-plant system under conditions of intensive forage cropping. Zeitschrift für Pflanzenernärhung und Bodenkunde 153: 291-292.

ERviö, R. \& SipPOLA, J. 1993. Micronutrient concentration of Italian ryegrass (Lolium multiflorum L.) grown on different soils in a pot experiment. Agricultural Science in Finland 2: 141-148.

JOKINEN, R. \& TÄHTINEN, H. 1987. Copper content of coarse mineral and peat soils and the growth of oats in a pot experiment. Annales Agriculturae Fenniae 26: 227-237.
-, URVAS, L. \& HYVÄrINEN, S. 1993. Uuttuva kupari viljellyissä eloperäisissä maissa. Summary: Extractable copper in cultivated organic soils. Suo 44: 11-19.

KolJonen, T. \& MalisA, E. 1991. Solubility in aqua regia of selected chemical elements occurring in fine fraction of till. Environmental geochemistry in northern Europe. Geological Survey of Finland. Special Paper 9: 49-52.

LAKANEN, E. \& ERVIō, R. 1971. A comparison of eight extractants for the determination of plant available micronutrients in soils. Acta Agralia Fennica 123: 223232.

Liang, J., Karamanos, R. E. \& Stewart, J. W. B. 1990. Distribution of zinc fractions in prairie soils. Canadian Journal of Soil Science 70: 335-342. 
-, Stewart, J. W. B. \& Karamanos, R. E. 1991. Distribution and plant-availability of soil copper fractions in Saskatchewan. Canadian Journal of Soil Science 71: 89-99.

Mclaren, R. G. \& Crawford, D. V. 1973. Studies on soil copper. I. The fractionation of copper in soils. Journal of Soil Science 24: 172-181.

Mullins, G. L. \& Martens, D., Gettier, S. W. \& Miller, W. P. 1982. Forms and availability of copper and zinc in a Rhodic Paleudult following long-term $\mathrm{CuSO}_{4}$ and $\mathrm{ZnSO}_{4}$ applications. Journal of Environmental Quality 11: 573-577.

NiSKANEN, R. 1989. Extractable aluminium, iron and manganese in mineral soils. II. Extractability by oxalate and pyrophosphate. Journal of Agricultural Science in Finland 61: 79-87.

RÄISÄNEN, M.-L. \& HÄMÄLÄINEN, L. 1991. Selective sequential dissolution of polluted and non-polluted sediments. Environmental geochemistry in northern Europe. Geological Survey of Finland. Special Paper 9: 157-162.

Shuman, L. M. 1979. Zinc, manganese, and copper in soil fractions. Soil Science 127: 10-17.

- 1985. Fractionation method for soil microelements. Soil
Science 140: 11-22.

SillanPÄÄ, M. 1982. Micronutrients and the nutrient status of soils: a global study. FAO Soils Bulletin 48: 1444.

Sippola, J. \& TARES, T. 1978. The soluble content of mineral elements in cultivated Finnish soils. Acta Agriculturae Scandinavica, Suppl. 20: 11-25.

TAINIO, A. 1963. Kuparilannoitteista, niiden käytöstä ja merkityksestä. Leipä leveämmäksi 11, 2: 12-16.

TäHTINEN, H. 1971. Copper content of the soil and the effect of copper fertilization. Acta Agralia Fennica 123: 136-142.

VIETS, F. G. Jr. 1962. Chemistry and availability of micronutrients in soils. Journal of Agricultural and Food Chemistry 10: 174-178.

Yli-Halla, M. 1993. Plant-availability of soil and fertilizer zinc in cultivated soils of Finland. Agricultural Science in Finland 3: 197-270.

Yläranta, T. \& SillanPÄÄ, M. 1984. Micronutrient contents of different plant species grown side by side. Annales Agriculturae Fenniae 23: 158-170.

Manuscript received April 1994

\title{
SELOSTUS
}

\section{Kupari Suomen viljelysmaissa}

\author{
MARKKU YLi-HaLla
}

Helsingin yliopisto

Viljelysmaiden muokkauskerroksen kuparivaroja tutkittiin määrittämällä kuparin $(\mathrm{Cu})$ kokonaismäärä sekä eri tavoin maahan sitoutuneita kuparin fraktioita. Kuparin kokonaismäärä $\left(6,9-97,4 \mathrm{mg} \mathrm{kg}^{-1}\right)$ oli suurin savimaissa (keskiarvo $59,0 \mathrm{mg} \mathrm{kg}^{-1}$ ) ja pienin karkeassa hiedassa ja moreenimaissa $\left(18,3 \mathrm{mg} \mathrm{kg}^{-1}\right)$. Kivennäismaissa kuparin kokonaismäärä oli vuorosuhteessa savespitoisuuden kanssa. Vesiliukoisen ja vaihtuvan kuparin sekä orgaanisen aineksen ja rauta- alumiini- ja mangaanioksidien sitoman kuparin summa oli kivennäismaissa $30 \%$ ja eloperäisissä maissa $53 \%$ kokonaismäärästä. Näitä osuuksia voidaan pitää potentiaalisesti kasveille käyttökelpoisina. Kummassakin maalajiryhmässä mineraalirakenteisiin sitoutuneen, kasveille käyttökelvottoman kuparin osuus oli suuri (kivennäismaissa $70 \%$, eloperäisissä maissa $47 \%$ ). Viljavuusana- lyysissä kupari uutetaan happamalla ammoniumasetaattietikkahappo-EDTA-liuoksella, pH 4,65 ( $\left(\mathrm{Cu}_{\text {EDTA }}\right)$. Tämä liuos uutti vaihtuvasta, orgaanisen aineksen ja oksidien sitomasta kuparista kivennäismailla $56 \%$ ja eloperäisillä mailla $71 \%$.

Muokkauskerroksen $\mathrm{Cu}_{\mathrm{EDTA}}$-varat olivat lähes poikkeuksetta suuremmat kuin jankon, mutta varsinkin savimailla juuristovyöhykkeen alapuolisissa maakerroksissa oli runsaasti $\mathrm{Cu}_{\mathrm{EDTA}}$. Perinteisesti turvemaiden on sanottu tarvitsevan kuparilannoitusta. Vaikka tässäkin aineistossa monessa turvemaassa kuparin kokonaismäärä oli pieni, oli useimmissa turvemaissa melko runsaasti $\mathrm{Cu}_{\text {EDTA }}$. Tästä syystä kuparilannoitus ei saa millään maalajilla olla automaattinen viljelytoimi vaan sen on perustuttava maa-analyysiin. 